\title{
VALUES OF BEING ANALYSIS IN R.J. PALACIO'S NOVEL “WONDER”
}

\author{
Safnidar Siahaan \\ English Department \\ University of Riau Kepulauan \\ kirei_akiko83@yahoo.com
}

\begin{abstract}
The purposes of this research are to find out the values of being described in R.J Palacio's novel based on Linda's Theory of Values. This research design was qualitative research. There are two sources in this research namely primary and secondary data source. The primary data focuses on the novel "Wonder" by R.J Palacio. The researcher also uses text or books that discussed Linda's theory of educational values and other literature related as the secondary data source to complete the research. The data collected based on the characters in the novel, such as: action, dialogues, thoughts, appearances, and reaction to other character which revealed in the novel. The result of the research only focuses on the value of being consisting of honesty, courage, peace and self-reliance and potential. The researcher hopes that this research can give the solution to the problems of education in our life. Moreover, the researcher hopes this novel is good for everybody to apply this value in daily life, especially for parents and teachers.
\end{abstract}

Keywords: Educational values, honesty, courage, peace and self-reliance and potential.

\section{INTRODUCTION}

Sometimes some people do not realize that what is being read or watched can be said as the result of the literary work. Moreover, some people will have the different perception about the literature. According to Klarer (2004:1), literature is referred to as the entirety of written expression. That mean people express what they feel or their imaginative thought in an interesting and beautiful form of artworks. There are several literary works such knowledge and novel can be one of a useful and interesting media to get new knowledge.

Novel as one of the examples of literature is a fictional story in writing and has intrinsic and extrinsic elements. It is usually tells about human life in its interaction with the environment and each other. In a novel, author makes every effort how to connect and show directly to the reader about the descriptions of the reality of life through the stories contained in the novel. According to Abrams (1999:190), the term "novel" is now apply to a great variety of writing that have in common only the attributes of being extended works of fictions written in 
prose. A novel also can be said as the combination of the author's experiences life and the imagination. It means most of the aspects in the real life of human will be presented in the novel by the author.

One way to attract the attention of the reader, the author of the novel generally creates the novel that contains the true story. One of the important things in the novel is element of the novel. There are two elements; those are: Intrinsic and extrinsic elements. In this research, the writer focuses on the extrinsic element analysis namely the values of being as a part of educational values.

There are several procedures to find the educational values in a novel. Education can be said as a process with certain methods so that people gain the knowledge, understanding, and how to behave in accordance with needs. Value is something such as quality, attitude, or method is its importance or usefulness. It can be concluded that the educational values is a process with certain methods that people not only gain the knowledge, understanding or how to behave in accordance but also about something such as attitude or quality for their life.

Values and literature are complementary and are inseparable. Literary works were born and sourced from human life and have a high value. Literature will be a contribution to the formation of values so that lovers of literature will be civilized, well-mannered, and virtuous men, and agreeing with the applicable rules. The values in the literature usually reflect the views of the author's life or values that are attractive to the author and are necessary to convey to the readers.

\section{Novel}

According to Stanton (as cited in Fitriani, 2012), a novel is one of genres literary work which presents in detail the enlargement of character, or complicate social circumstances, or a relation between many personalities. It is compose of many different phenomenon and intricate relationships surround by a few people in the novel. Novel can be said as one of literary work that is interested by people from different generation. For some people who make the reading activity as the habit and hobby, then the novel can be used as an alternative to learn and experience foreign situations and to entertain. Therefore, novel is one of literary works that interested by people from different generation and novel refers as one of literary 
works that have the form of a long prose narrative that created by the author's imagination or it can be also based on a true story.

\section{Novel Types}

According to Klarer (2004:11-12) there are several types of novel as follows:

A. Picaresque Novel

According to Klarer (2004:11), picaresque novel is a novel that depicts the adventures of a rascal or trickster among the various social classes. It is means a picaresque is a novel that related to adventure stories. For example is The Adventures of Huckleberry Finn by Mark Twain or Gulliver's Travels by Jonathan Swift.

B. The Bildungsroman

According to Klarer (2004:11), bildungsroman or also knows as novel education, also called a coming of age story that means all about the moral and psychological growth of the main character. The protagonist in the novel finds himself or herself in a better of happier place by the last page. In many cases, that growth entails recognition of the harsh truth of reality. For example is Ender's Games by Orson Scott Card.

C. The Epistolary Novel

According to Klarer (2004:11), the term epistolary drawn from word "Epistle" means "Letter". The novel is made up of letter and diary entries. Epistolary novel presented the story through a letter as the medium of the first person's narration. For example is The Color Purple is made up of letter is important also because the letters themselves are a crucial part of the story.

D. Historical Novel

According to Klarer (2004:12), historical novel is present the story based on the real context or a realistic historical context with element and/or historical figures are included. For example is The Ides of March by T. Wilder. This novel tells about the assassination of Julius Caesar in Rome.

E. The Satirical Novel

According to Klarer (2004:12), the satirical novel as art that ridicules a specific topic in order to provoke readers into changing their opinion of it. The novel related to literary works that provoke the reader and changing the reader opinion in the story. Example:

F. Utopian Novel 
According to Klarer (2004:12) utopian novel or science fiction novels create alternative worlds as means of criticizing real socio-political conditions, as in the classic Nineteen Eightyfour by George Orwell.

\section{G. The Gothic Novel}

According to Klarer (2004:12), gothic novel is a style of writing that is characterized by elements of fear, horror, death, and gloom, as well as romantic elements such as nature, individuality, and very high emotion. Example: Dracula.

\section{H. Detective Novel}

According to Klarer (2004:12), detective novel is a novel in which a detective tries to solve a crime, or novel in which the reader is challenged to solve a puzzle before the detective explain it at the end. Example: murder on the orient express by Agatha Christie.

Based on different types of novel above, it can be concluded that novel can be presented by the author with different structure or arrangement. The process of makes a novel depends on the author. The story can come from the author's imagination or it can come from the true story. The true story could be based on what the author has experiences or also based on other people's experience. In this analysis, Wonder by R.J Palacio's Novel is the Bildungsroman.

\section{Education}

According to Thornburg (as cited in Türkkahraman, 2014), Education is a process to educate which aims at biological, psychological, social and moral development of human being, who is a member of the society. To educate is not only about technical, methodology and mechanical off passing skill to the children, but also it is an activity that has dimension and element of art to dedication, emotional compassion in effort to build and shape the personality.

Based on definition above, the researcher concludes that education is an effort to create an atmosphere of learning and the learning process so that learners actively developing the potential for them to have the spiritual strength of religious, self-control, personality, intelligence, and skills needed themselves and society.

\section{Educational Value}

According to Mashita (2013), educational values is an effort of people through teaching and training to change their behaviour and attitudes toward maturity to obtain a balance between the relationship of reason and feeling so that the balance of interaction in society is realized. 
Educational value is the value of education. Educational values are the results of valuing process of comprehension and implementing of God and humanity values in life. So, these values will guide human knowledge and creativity appropriately. Moreover, according to Linda (1993:03), there are some kinds of the education values which divided into two groups. There are values of being and values of giving. In this research, the writer only analyses the value of being.

\section{Value of Being}

According to Linda (1993:29), the values of being are given as they are gained-practiced on the "outer" as they are developed in the "inner". They begin with the development of quality or an attitude within ourselves that determines how we behave and how we treat others. In values of being, there are divided into four parts are follows;

\section{A. Honesty.}

According to Linda (1993:41), honesty is one of the values being towards other individuals, institutions, society, and ourselves. Characteristic of honesty is when someone speaks and acts truly like nothing to hide. For example, when the child does not feel good, she will tell her mother what she feels. Or when a boy make a mistake like broke his parent's stuff, he will try to tell his mother or father for what his doing and make apologize for what he does.

\section{B. Courage}

According to Linda (1993:56), courage is dare to doing the right thing when it is hard. Dare to say no and mean it and influence other people for being good. Dare to be true to convictions and following good impulses even they are unpopular. Standing up for what you believe. Dare to be gracious and friendly to others. For example, a boy moves to a new school. He will meet a new people, a new friend. That makes the boy trying to have a social interaction with classmate to make a friend in a new school.

C. Peace

According to Linda (1993:76), the meaning of peace is calm and patient attitude. Understand that the differences are rarely resolved through conflict. Peace does not mean the elimination or ignoring of emotions. Rather, it means to control them and to prevent their causing hurt to other people. For example, to make situation in school or home calmer, you must try to respond to every negative remark with a positive one. Controlling the tone and decibel 
level of your own voice, try to talk more softly. Put your hand on a shoulder or arm as you speak to someone. Control your emotion before you control others emotion.

D. Self-reliance and Potential

According to Linda (1993:90), self-reliance is about trying to know ourselves, to do our best, and to accept the consequences both of who we are and what we do. Self-reliance has a lot to do with taking the blame or the responsibility for negative things that happen. While, potential has a lot to do with taking the right kind of pride in what we are able to become and what we are able to accomplish.

\section{Function of Educational Value}

According to Turkkahraman (2013), the function of Educational value is to create values and raise individuals who convert their values to behaviours. Values cannot be gained by telling or describing. They should be experienced directly, internalized and should be given with the feelings related to them. Values become identities by experience. The precondition of the values education is to prepare environment to the child where he can use his freewill. The education which is given by insisting, oppression and conditioning leads to actualization others requests rather than its own.

According to Nickolov (as cited in Turkkahraman, 2013), one of the primary goals of education is to give the individual confidence and the consciousness of being an individual. The individuals who are not given that consciousness and subject to excessive socialization cannot be creative. In the excessive socialization, uploading knowledge predominates rather than knowledge generation. Lack of confidence and creativeness effects social development in a negative way. In that case, the societies have to make the individuals become active members of the society by teaching them the values that they have.

\section{METHODOLOGY}

This research is qualitative descriptive method aims to obtain in-depth data and close reading of the text, a data contains the meaning. According to Creswell (2009:03) research design is the plans and the procedures for the research that span the decisions from broad 
assumptions to detailed methods of data collection and analysis. There are several types of research design such as qualitative, quantitative, and mixed methods. In additional, according to Kothari (2004:31), a research design is the arrangement of conditions for collection and analysis of data in a manner that aims to combine relevance to the research purpose. That means the research design is the conceptual structure within which research is conducted; it constitutes the blueprint for the collection, measurement and analysis of data. Moreover, Sarwono (2006:197) stated that every research design is supported by theories as the foundation. Therefore, in this research, the writer decides to use qualitative research as research design for this analysis. The writer intends to describe the values of being in R.J Palacio Novel "Wonder" by using Linda's Theory (1993). The writer used primary and secondary data in this analysis. Kothari (2004:95) explained that the primary data source is the data that use as the main data in a research and the primary data are those which are collected a fresh and for the first time and thus happen to be original in character. According Kumar (2011:347) secondary data refer to the data which already available in other source and other researcher extract that information. The secondary data source is the data that use to support primary data analysing. In addition, Kothari (2004) stated the secondary data are those which have already been collected by someone else and which have already been passed through the statistical process. Therefore, the writer used novel "Wonder" by R.J Palacio as the primary data source and the text or books that discussed Linda's theory of educational values and other literature related as the secondary data source to complete the analysis.

\section{RESULTS}

\section{Value of Being in the novel}

According to Linda (1993), Values of being are given when the children are gainedpracticed on the "outer" as they are developed in the "inner". Thus, they begin with the development of quality or an attitude within ourselves that determines how we behave and how we treat others.

\section{a. Honesty}

According to Linda (1993:41) honesty means told the truthfulness story, towards other individuals, institutions, society, and ourselve. It leads the strength and confidence that comes 
from ourselves because there is nothing to hide. Thus, characteristic of honesty is they speak and act truly like nothing to hide. They tell other people how they feel. Therefore, based on the analysis, the writer found several data that showed educational value of being; honesty as follows:

\section{Data 1}

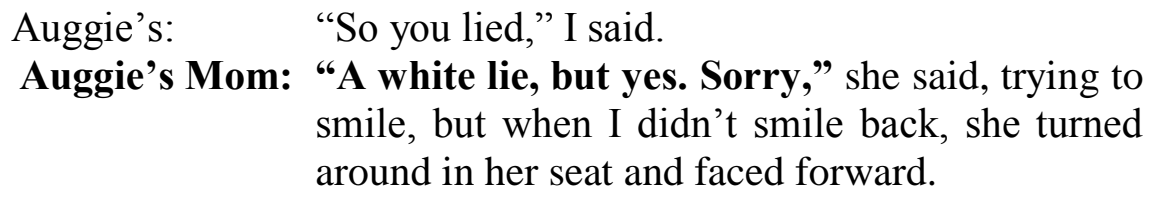
smile, but when I didn't smile back, she turned around in her seat and faced forward.

\section{(Palacio, 2012, P. 11-12)}

Based on the data 1, Auggie's Mom apologized to Auggie that she lied and did not tell him about the school before. His mom afraid that Auggie will be refused if they told to Auggie first about the school and Auggie's mom told that she feel sorry for not telling him and Auggie mad because his mom not telling him first about school. Based on the explanation above, Auggie's mom indicates that she tells the truth to Auggie, and she feels sorry about not telling Auggie first. Auggie's mom knows that she doing wrong but she directly say apologize to Auggie because she lie to him. The writer found the characteristic of the honesty is speaks truly like nothing to hide in the data that Auggie's mom tells the truth to Auggie and apologize to Auggie because she lied to Auggie before.

After that, Auggie makes a deal with his mom and next day he is going to school with his mom. When he arrived to the school, he met the principal and the principal introduced some kids to Auggie and the principal told to some kids to look around the school with Auggie, and Auggie's mom and principal could talk something after that. In the data, Auggie's mom asked to Auggie how he felt after looking around the school with some kids. And it can be seen in the conversation below:

\section{Data 2}

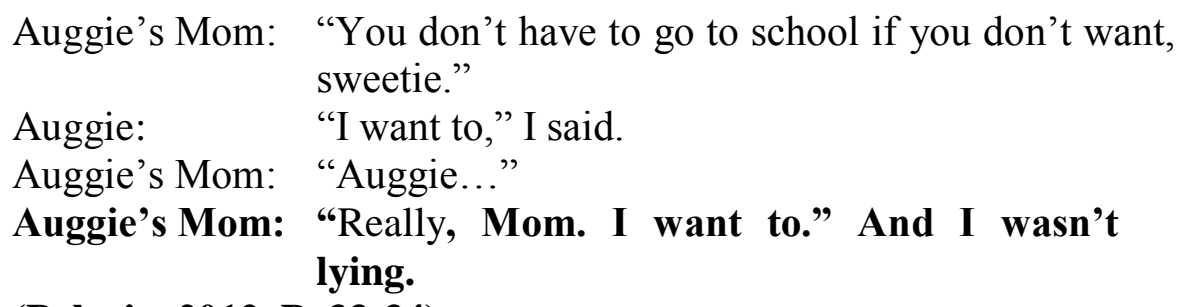

(Palacio, 2012, P. 33-34) 
In the data 2 above, Auggie told his true feeling after meet some kids in the school. His mother worried if Auggie did not feel comfortable in that school, but Auggie tries to persuade his mom that he is fine and want to go to school. Even his mom still worry that would be hurt him, and again Auggie makes his mom not to worry. Based on the conversation above, it can be explained that Auggie showed the value of being; honesty to his mom for what he thinks about school.

\section{b. Courage}

According to Linda (1993:56) courage is dares to doing the right thing when it is hard. Dare to say no and mean it and influence other people for being good. Dare to be true to convictions and following good impulses even they are unpopular. Standing up for what you believe. Therefore, based on the analysis, the researcher found the data that showed educational value of being; courage as follows:

\section{Data 3}

"I would have been more nervous about meeting Mr. Tushman if I'd known I was also going to be meeting some kids from the new school. But I didn't know, so if anything, I was kind of giggly. I couldn't stop thinking about all the jokes Daddy had made about Mr. Tushman's name. So when me and Mom arrived at Beecher Prep a few weeks before the start of school, and I saw Mr. Tushman standing there, waiting for us at the entrance, I started giggling right away. He didn't look at all like what I pictured, though." (Palacio, 2012, P. 15)

The data based on Auggie point of view after some argumentation with his mother. At first Auggie tried to refuse to go to school. Though her mother keep encourage him to go with some agreement. Thus the data showed Auggie's point of view about how nervous he is meeting with The Principal. How he never meet stranger before and how at the end Auggie is encourage himself to be brave and agree to meet the Principal even though he is afraid to meet a new person.

The writer finds the courage in the data that Auggie doing the right thing when it is hard for Auggie. That means, in the first Auggie really hate to go to the school because he afraid when someone see his face and telling the bad thing about his face, but right now Auggie tries to dares to go to school and out from his comfort zone. 


\section{c. Peace}

According to Linda (1993:76), peace is calm and patient attitude. Understand that the differences are rarely resolved through conflict. Peace does not mean the elimination or ignoring of emotions. Rather, it means to control them and to prevent their causing hurt to other people. Therefore, based on the analysis, the researcher found the data that showed educational value of being; peace as follows:

\section{Data 4}

So here's why I changed my mind. It wasn't so I wouldn't have to hear Mom give me a whole lecture. And it wasn't to protect this August kid from Julian, who I knew would be a jerk about the whole thing. It was because when I heard Jamie talking about how he had run away from August going 'Ahhh,' I suddenly felt really bad. The thing is, there are always going to be kids like Julian who are jerks. But if a little kid like Jamie, who's usually a nice enough kid, can be that mean, then a kid like August doesn't stand a chance in middle school.

(Palacio, 2012, P. 140-141)

Based on the conversation above, Jack is trying to not make anything bad. He accepts what his mom asking and trying to understand the situation. Jack talking to himself to control and not to make someone hurt again. So, he accepts to meet Auggie and not to run away for anything. Therefore, the researcher can make a conclusion that Jack trying to control his ego.

The writer finds value of being; peace in the data. The characteristic of the peace is to control and to prevent their causing hurt to other people. So, the researcher finds the data is peace because Jack controls his ego, listens to his mom and trying to help Auggie.

\section{d. Self- reliance and Potential}

According to Linda (1993:90), self-reliance is about trying to know ourselves, to do our best, and to accept the consequences both of who we are and what we do. And potential has a lot to do with taking the right kind of pride in what we are able to become and what we are able to accomplish. Therefore, based on the analysis, the researcher found the data that showed educational value of being; self-reliance and potential as follows:

\section{Data 5}


So I've gotten used to not complaining, and I've gotten used to not bothering Mom and Dad with little stuff. I've gotten used to figuring things out on my own: how to put toys together, how to organize my life so I don't miss friends' birthday parties, how to stay on top of my schoolwork so I never fall behind in class. I've never asked for help with my homework. Never needed reminding to finish a project or study for a test. If I was having trouble with a subject in school, I'd go home and study it until I figured it out on my own. I taught myself how to convert fraction into decimal points by going online. I've done every school project pretty much by myself.

(Palacio, 2012, P.82-83)

It is based on Via: Auggie's sister point of view about how her parents treat her since Auggie exist. She has done anything by herself. Never ask her parent to help her because she understands the situation and do not try to bother her parent. Even she always wants her parent looking and helping her, but again she tries to understand the situation and that makes her more independent. The researcher finds self-reliance and potential in the data based on Via point of view. Self-reliance is about trying to know ourselves, to do our best like what Via do, and potential is has a lot of to do with taking the right kind of pride in what we are able to become and what we are able to accomplish like what Via do.

This analysis is about R.J Palacio's novel "Wonder". It describes about Educational values in "Wonder" novel by using Linda's theory. The theory explains about Educational Values. There are two values; values of being and values of giving. Value as the standards of our actions and attitudes of our hearts and minds that will shape who we are, how we live, the choice we make and how we treat other people (Linda, 1993). In this research, the writer only analyses value of being as part of educational value in Linda's theory. The writer found 5 data for value of being.

\section{REFERENCES}

Abrams, M. H. (1999). A Glossary of Literary Terms (7 Ed). Boston: Heinle \& Heinle.

Creswell, J. W. (2009). Research Design Qualitative, Quantitative, and Mixed Methods Approaches (4th ed.). London: SAGE Publications, Inc.

Fitriani, R. (2012). An Analysis Of Moral Values In Novel "Oliver Twist" By Charles Dickens. English Study Program, University of Pasir Pengaraian, 3. 
Klarer, M. (2004). An Introduction to Literary Studies. New York: The Taylor \& Francis.

Kothari, C. R. (2004). Research Methodology: Methods and Techniqued. New Delhi: New Age International.

Kumar, R. (2011). RESEARCH METHODOLOGY. (I. Digitals (P) Ltd, Chennai, Ed.) (3rd ed.). Mathura Road New Delhi: SAGE Publication India Pvt Ltd.

Linda, R. E. (1993). Teaching Your Children Values. New York: Fireside.

Mashita, M. (2013). Nilai-Nilai Pendidikan Dalam Novel Sepatu Dahlan Karya Khrisna Pabichara Dan Implikasinya Dalam Pembelajaran Bahasa Indonesia. Padang: Universitas Negeri Padang.

Sarwono, J. (2006). Metode Penelitian Kuantitatif Dan Kualitatif. Yogyakarta: Graha Ilmu.

Turkkahraman, M. (2013). Social Values and Values Education. Procedia-Social and Behavioral Sciences. 